\author{
Wojciech GAGATEK \\ Uniwersytet Warszawski \\ w.gagatek@uw.edu.pl
}

\title{
JACEK CZAPUTOWICZ, KAMIL ŁAWNICZAK, ANNA WOJCIUK, NAUKA O STOSUNKACH MIĘDZYNARODOWYCH I STUDIA EUROPEJSKIE W POLSCE
}

\author{
Wydawnictwo Naukowe Scholar, Warszawa 2015, 196 s.
}

Jest źle - tyle można by powiedzieć, aby w dwóch słowach streścić stan nauki o stosunkach międzynarodowych i studiów europejskich w Polsce przedstawiony w książce Jacka Czaputowicza, Kamila Ławniczaka i Anny Wojciuk. Co więcej, jest źle od bardzo dawna - 25 latom transformacji nie towarzyszyło uzyskanie przez polskich badaczy większego wpływu na naukę europejską czy światową. Do tego nie wygląda na to, aby $\mathrm{w}$ krótkiej perspektywie miało się w tym przedmiocie coś zmienić.

Napisanie recenzowanej książki było bardzo potrzebne. Głosy o tym, iż polska nauka o stosunkach międzynarodowych i studia europejskie (czy też generalnie nauki społeczne w Polsce) stoją na niskim poziomie, są bowiem często słyszane podczas kongresów, paneli czy seminariów naukowych (choć zdarzają się też zdania bardziej optymistyczne). Do tej pory niewiele było jednak prac oferujących dane empiryczne, które mogłyby rzucić więcej światła na to zagadnienie (poza łatwo dostępnymi wskaźnikami bibliometrycznymi dotyczącymi cytowań i impact factor). Recenzowana praca wypełnia tę lukę, oferując oryginalny materiał empiryczny, oparty na jakościowej i ilościowej analizie treści czasopism naukowych oraz prac doktorskich i habilitacyjnych. $\mathrm{Na}$ tej podstawie autorzy przeprowadzili analizę przyczyn tego stanu rzeczy i wysnuli postulaty dotyczące jego naprawienia. W szczególności interesuje ich określenie stopnia, $\mathrm{w}$ jakim polscy badacze stosują teorie i metody badawcze w publikowanych przez siebie pracach, jak sami postrzegają swoją dyscyplinę oraz jak wypadają pod tym względem na tle innych państw (s. 10). Książka jest wynikiem realizacji grantu badawczego z NCN. Jest to znakomita, dobrze napisana, a co najważniejsze - dająca do myślenia pozycja, która powinna stać się najważniejszym punktem odniesienia w dyskusji o stanie nauki o stosunkach międzynarodowych i studiach europejskich w Polsce. W krótkiej z natury 
rzeczy recenzji nie jest możliwe dogłębne ustosunkowanie się do wszystkich przedstawionych w tej publikacji argumentów, dlatego też poniżej chciałbym syntetycznie przedstawić główne ustalenia autorów oraz zgodnie z tym, co sami postulują, pisząc o braku w Polsce jakże potrzebnego krytycznego dialogu naukowego, wskazać na kilka elementów wymagających dalszych badań.

Nauka o stosunkach międzynarodowych (dalej: SM) sięga swoimi korzeniami XIX w. W Polsce pierwsze prace w tym obszarze powstały już w okresie międzywojennym i, co bardzo ważne, do końca lat 40 . XX w. polscy badacze SM stanowili nieodtaczna czesść europejskiej, a w pewnym sensie i amerykańskiej sieci badaczy (s. 39). Zapaść datuje się mniej więcej od lat 50. XX w., wraz ze zmianami politycznymi w PRL, zamknięciem się (dosłownym i w przenośni) na naukę światową, w tym poprzez stosowanie jedynie słusznego marksistowskiego pojmowania stosunków międzynarodowych. Słabość nauki o stosunkach międzynarodowych, jeśli chodzi o kwestie koncepcyjne, metodologiczne i teoretyczne, zauważano już w PRL (L. Pastusiak). Natomiast studia europejskie (dalej: SE), które autorzy uznają raczej za obszar badawczy niż subdyscyplinę (nie omawiając dogłębnie tego zagadnienia), w latach 90. rozwijały się w ściśle utylitarnym kierunku, aby przygotować społeczeństwo, a zwłaszcza kadry urzędnicze i ekspertów, do członkostwa w Unii Europejskiej. Ich rozwój jako obszaru wiedzy przyspieszył wraz z otwarciem na początku pierwszej dekady XXI w. kierunku studiów o nazwie europeistyka.

Niezależnie od różnych punktów wyjściowych ocena dorobku SM i SE w recenzowanej książce jest bardzo podobna. Większość polskich badaczy nie publikuje za granicą, nie uczestnicząc tym samym w międzynarodowym obiegu naukowym. Do tej pory słyszało się, że wynika to z braku biegłej znajomości języków obcych. Autorzy wskazują, że przyczyna tkwi głębiej, a jest nią brak umiejętności prowadzenia badań naukowych, znajomości i stosowania metodologii i teorii, a nawet sposobu pisania tekstów naukowych według omawianego przez nich dominującego wzorca typowego dla badań amerykańskich i brytyjskich, opartego w dużej mierze na teoretycznie ukierunkowanych badaniach ilościowych, modelach formalnych i teorii racjonalnego wyboru. Stwierdzają, że większość polskich prac jest zupełnym przeciwieństwem powyższego standardu: są ateoretyczne, opisowe (a nie analityczne), nie zawierają żadnych rozważań metodologicznych, ujęcia analitycznego, a czasami nawet pytań badawczych. W większości są to analizy tylko jednego czy też bardzo ograniczonej liczby przypadków, a nie analizy porównawcze. Nie tylko brak w nich zastosowania metod ilościowych, ale występuje również sytuacja, którą autorzy określili jako intuicyjne stosowanie metod jakościowych, odbiegające od zasad sztuki (s. 133). Posuwają się nawet do stwierdzenia, że taki opisowy styl niewiele różni się od stojącego na wysokim poziomie merytorycznym dziennikarstwa (s. 134). Taki obraz wyłania się z analizy zawartości czasopism naukowych, treści artykułów, doktoratów i habilitacji z ostatnich 25 lat (choć zdarzają się oczywiście wyjątki), a także podręczników zalecanych studentom. $84 \%$ doktoratów to prace ateoretyczne, podczas gdy dla artykułów naukowych ten wskaźnik wynosi 90\%. Co więcej, artykuły opublikowane w czasopismach są bardzo rzadko cytowane (pytanie, czy to samo dotyczy ich czytania), przynajmniej jeśli wziąć pod uwagę bazę Google Scholar. Jak bowiem zinterpretować fakt, że 53 artykuły, które ukazały się w latach 2007-2012 
w czołowym czasopiśmie „Stosunki Międzynarodowe”, były cytowane tylko 90 razy, zaś najczęściej cytowany artykuł (R. Zięby) uzyskał tylko sześć cytowań? To z kolei może po części wynikać z braku wymiany poglądów i głosów polemicznych w czasopismach. Jednakże pozwoliłem sobie sprawdzić cytowania wspomnianego profesora Ryszarda Zięby i zauważyłem, że pierwsze siedem pozycji na jego liście cytowań stanowią książki, w tym Instytucjonalizacja bezpieczeństwa europejskiego. Koncepcje, struktury, funkcjonowanie (1998), która była cytowana 80 razy, oraz np. Wspólna polityka zagraniczna i bezpieczeństwa Unii Europejskiej (2007), cytowana 38 razy. Dla porównania żaden z jego artykułów w czasopismach naukowych nie uzyskał więcej niż dziewięć cytowań. Podobna struktura, jeśli chodzi o proporcje cytowań książek w stosunku do artykułów, jest charakterystyczna dla innych polskich badaczy SM: Józefa Kukułki, Romana Kuźniara, Ziemowita Jacka Pietrasia, Teresy Łoś-Nowak, Edwarda Haliżaka, Marka Pietrasia. Remigiusza Bierzanka (wymienionych w kolejności najbardziej wpływowych badaczy według respondentów ankiety TRIP, zob. poniżej), a także po części Jacka Czaputowicza, którego listę cytowań otwierają dwie pozycje książkowe, natomiast na trzecim miejscu jest anglojęzyczny artykuł. Sprawdziłem również strukturę cytowań czołowych polskich europeistów średniej i starszej generacji i sytuacja wygląda podobnie. Może więc w Polsce nie czyta się po prostu czasopism naukowych, a preferuje książki ? A może należy posługiwać się innymi miernikami niż cytowania?

Niezależnie od powyższego, w perspektywie porównawczej polskie badania SM i SE są najbliższe ateoretycznemu wzorcowi SM obecnemu we Francji, gdzie metody ilościowe nie są popularne, unika się debat i polemik, zaś dąży do jak najbardziej wszechstronnego i rozbudowanego o pis u możliwe maksymalnej liczby zagadnień. Natomiast w zestawieniu ze standardem anglosaskim ustalenia autorów to de facto radykalne i frontalne podważenie legitymizacji całego środowiska naukowego. W szczególności autorzy mają na myśli grupę badaczy stosunków międzynarodowych określoną przez nich jako „kontynuatorzy" (w domyśle: tradycji badawczej ukształtowanej w PRL, ze wszystkimi jej wadami i słabościami, w tym przede wszystkim izolacją od nauki światowej, która za patrona obrała sobie Józefa Kukułkę), zaś sami określają siebie jako „uniwersalistów”, czyli grupę, która stara się dołączyć do szerokiej międzynarodowej społeczności badaczy (czego symbolem jest Ludwik Ehrlich). Oliwy do ognia dolewa fragment recenzji wydawniczej autorstwa Jana Zielonki z Uniwersytetu w Oxfordzie umieszczony na okładce, w którym stawia on hipotezę, iż problemy polskiej nauki wynikaja z kultury uniwersyteckiej w Polsce, ze swoistego typu feudalizmu, który kultywuje stare hierarchie, powiazania, obyczaje i blokuje rozwój intelektualny ludzi mtodych. Dawno nie spotkałem się z tak radykalną i dosadną krytyką własnego środowiska naukowego.

Najmocniejszą stroną książki jest oparcie zawartych w niej argumentów na danych statystycznych zebranych przez autorów. Rozważania dotyczące Polski poprzedza szczegółowa analiza historii stosunków międzynarodowych w kraju i na świecie, zaś porównywanie trendów badawczych jest możliwe w oparciu o przeprowadzony w Polsce i administrowany przez autorów projekt TRIP (Teaching, Research and International Policy). Bardzo dobrze, iż autorzy zdecydowali się na wzbogacenie kategorii analitycznych badania TRIP 
o kategorie dostosowane do polskiego kontekstu. Wydaje mi się jednak, że część dotycząca stosunków międzynarodowych jest napisana nieco lepiej i bardziej dogłębnie niż ta dotycząca europeistyki. Jest tak być może dlatego, że historia tej pierwszej dyscypliny jest znacznie dłuższa oraz że autorzy dysponowali wynikami projektu TRIP, ale mimo to można było bardziej dogłębnie przedstawić narodowe modele studiów europejskich, tak samo jak autorzy uczynili w przypadku stosunków międzynarodowych.

Ale zasadnicze pytanie dotyczy zestawienia w jednej książce stosunków międzynarodowych i europeistyki (autorzy nie wyjaśniają przyczyn takiego doboru przypadków), które oczywiście mają wiele punktów wspólnych (takich jak wielodyscyplinarność), ale równocześnie sporo rozbieżności wynikających właśnie z odmiennych wkładów dyscyplinarnych. Używając języka metodologii, należałoby zadać pytanie: czy zestawienie nauki o stosunkach międzynarodowych i studiów europejskich stanowi porównawcze studium przypadku, czy też dwa przypadki analizowane oddzielnie, a niezależnie od tego, czy mamy do czynienia z przypadkami skrajnie dewiacyjnymi, czy może jeszcze z inną odmianą studium przypadku? Autorzy omówili bowiem studia europejskie w zasadzie tylko z pespektywy nauk o polityce (piszą: poziom SE w Polsce jest w gtównej mierze pochodna poziomu nauki o polityce, s. 136), natomiast w znacznie mniejszym stopniu z perspektywy podejść prawniczych, ekonomicznych czy kulturowo-socjologicznych, które przecież odgrywają bardzo istotną rolę w definiowaniu zakresu badawczego studiów europejskich. Ponadto z pewnością w naukach prawnych, a być może także w innych obszarach szeroko rozumianej europeistyki, obowiązują inne standardy, jeśli chodzi o rolę i zastosowanie teorii i metodologii, które należałoby wziąć pod uwagę przy ocenie ogólnej kondycji studiów europejskich. Z drugiej strony stosunki międzynarodowe znajdują się blisko studiów europejskich, w szczególności z uwagi na fakt, że najpopularniejszym zagadnieniem omawianym przez znawców SM w ich artykułach są studia europejskie (dotyczy tego 17,8\% wszystkich artykułów, podczas gdy druga w kolejności analiza polityki zagranicznej państwa innego niż Polska obejmuje 15,7\% wszystkich artykułów). Warto by było, aby autorzy doprecyzowali, co mieli na myśli, pisząc o stosowaniu, przywoływaniu czy też odnoszeniu się do teorii. Przykładowo autorzy piszą: spośród teoretyków SM najczęściej przywotywano Samuela Huntingtona (w 5 artykutach), Immanuela Wallersteina (w 3), oraz Benjamina Barbera i Francisa Fukuyama (po 2 teksty) (s. 101). Nie wiem jednak, co dokładnie mają na myśli: czy to, że autor artykułu bądź doktoratu wspomniał, iż jakieś teorie istnieją, ewentualnie zacytował główne ich ustalenia, czy też że zastosował daną teorię w celu wyjaśnienia problemu badawczego?

Niewielkim pocieszeniem jest fakt, iż sytuacja w innych państwach naszego regionu niewiele odbiega od tej scharakteryzowanej w Polsce. Jako remedium autorzy proponują zwiększyć nacisk i poprawić jakość nauczania teorii i metodologii na studiach doktoranckich (s. 138), a także podczas studiów I i II stopnia, w tym wprowadzić szkolenia z techniki pisania artykutów naukowych wedtug obowiazujacego standardu. $\mathrm{Z}$ tą propozycją należy się oczywiście w całej rozciągłości zgodzić, pytanie tylko - jak ją zrealizować. Mam nadzieję, że recenzowana książka stanie się istotnym punktem wyjściowym w tej właśnie dyskusji, zaś sposób analizy stanu SM i SE będzie modelem także dla innych dyscyplin i dziedzin nauki. 